\title{
Kebijakan Post Border dan Ketidakpastian Regulasi Pemeriksaan Barang Impor di Indonesia
}

Surjadi Basuki ${ }^{*}$

* Email: surjadi.a@ui.ac.id
a Dept.IImu Ekonomi FEB-UI Kampus UI Depok,
Jawa Barat
Riwayat artikel:
- Diterima 28 Juli 2020
- Direvisi 10 September 2020
- Disetujui 16 September 2020
- Tersedia online 24 Oktober 2020

* Email:surjadi.a@ui.ac.id

Dept.IImu Ekonomi FEB-UI Kampus UI Depok,

Riwayat artikel:

- Diterima 28 Juli 2020

- Disetujui 16 September 2020

- Tersedia online 24 Oktober 2020

\begin{abstract}
The "post-border" policy, an import inspection policy enacted since February 1, 2018, is aimed at easing custom procedure for imported goods which are also becoming raw materials for domestic products. A harmony between a policy and its implementation progress should always be monitored. This study aimed at evaluating the effectiveness of the import inspection policy in providing ease and certainty for the business sector. Given the policy has been manifested in a series of regulations, the methodology chosen is the Regulatory Impact Assessment (RIA). The study finds hurriedness in constructing the regulations that lead to several unintended impacts. The inexistence of a standard in choosing the commodities that should follow the "post-border" procedures is a crucial issue that should be responded quickly in term of policy revision.
\end{abstract}

Key words : trade policy, policy coordinating; import inspection.

JEL Classification: F13, F19 


\section{PENDAHULUAN}

Efisiensi proses kepabeanan, khususnya untuk barang impor, terus ditingkatkan pemerintah Indonesia paling tidak sejak diterbitkannya UU No.17 Tahun 2006 tentang Kepabeanan yang merevisi UU No.10 Tahun 1995. Barang-barang impor yang mengalami pelarangan atau pembatasan ("lartas") selama ini berpotensi untuk mengalami proses kepabeanan yang banyak memakan waktu karena harus mematuhi sejumlah peraturan di bawah kewenangan Kementerian/Lembaga teknis. Misalnya, impor untuk kelompok "Produk Hortikultura" harus memeroleh rekomendasi dari Kementerian Pertanian dan mengikuti ketentuan-ketentuan dalam Peraturan Menteri Perdagangan (Permendag) No.71/MDAG/PER/9/2015 tentang Ketentuan Impor Produk Hortikultura.

Pada tanggal 15 Juni 2017, pemerintahan Presiden Joko Widodo mengeluarkan Paket Kebijakan Ekonomi XV yang berfokus pada pengembangan usaha serta peningkatan daya saing para penyedia jasa logistik nasional (Kemenko Perekonomian RI, 2017). Salah satu isu krusial dari Paket ini adalah bagaimana mempermudah arus barang impor lartas, terutama yang menjadi bahan baku bagi industri domestik Indonesia. Paket kebijakan ini mengubah proses pemeriksaan ribuan jenis barang impor lartas yang sebelumnya dilaksanakan di wilayah pabean (border) menjadi dilakukan "di luar kawasan pabean", yang oleh pemerintah disebut sebagai "post border". Secara singkat kebijakan ini kemudian disebut sebagai "kebijakan post border". Ditargetkan terjadi penurunan kuantitas jenis barang impor lartas yang diperiksa di kawasan pabean (border) serta peningkatan pemeriksaan kuantitas jenis barang impor lartas di luar kawasan pabean (post border). Sebelum adanya kebijakan post border, pemeriksaan atas pemenuhan ketentuan-ketentuan barang impor lartas tersebut dilakukan oleh aparat-aparat Ditjen Bea dan Cukai Kemenkeu di wilayah pabean. Kebijakan post border mengatur pemeriksaan tersebut di luar kawasan pabean (misalnya di gudang milik importir) dan pengawasnya adalah aparat-aparat Kementerian/Lembaga teknis sesuai dengan jenis produk yang terkena lartas.

Kebijakan post border mungkin dapat membuat barang impor lebih cepat keluar dari pelabuhan sebagai kawasan pabean. Namun ternyata sejumlah ketidakpastian telah muncul. Pertama adalah kepastian waktu dan biaya yang harus ditanggung oleh importir. Sebuah diskusi publik yang diselenggarakan oleh harian Bisnis Indonesia, mengungkapkan keluhan sebuah asosiasi importir nasional tentang risiko lebih besarnya biaya yang harus dikeluarkan oleh importir selama proses penimbunan hingga selesai pemeriksaan dibandingkan proses serupa di kawasan pabean (Pratomo, 2017). Hal ini dapat terjadi karena adanya kendala keterbatasan sumber daya pengawas yang dimiliki oleh Kementerian/Lembaga yang memiliki kewenangan atas barang-barang lartas. Sumber daya pengawas ini dinilai tidak memiliki kapasitas yang memadai untuk melaksanakan tugas pemeriksaan di post border (Prima, 2019).

Ketidakpastian berikutnya adalah mengenai kondisi barang impor jalur post border yang beredar di masyarakat. Ada risiko barang impor diedarkan oleh importir sebelum dilakukan pemeriksaan, sehingga menimbulkan gangguan terhadap pasar domestik atau munculnya risiko barang impor yang diedarkan tidak memenuhi Standar Nasional Indonesia (SNI) sehingga menyebabkan tidak terlindunginya konsumen. Media massa melaporkan terjadinya sejumlah pelanggaran berupa barang impor lartas wajib ber-SNI (yang diperiksa di post border) tanpa disertai label SNI (Suwiknyo, 2018).

Lebih lanjut, menurut laporan Kementerian Perindustrian RI, setelah regulasi ini diberlakukan, nilai impor dari beberapa produk yang di-post border-kan (bergeser pengawasannya menjadi post border) diduga mengalami lonjakan, termasuk di antaranya produk pupuk, kosmetik dan Perbekalan Kesehatan Rumah Tangga (PKRT), ban, ubin keramik, 
pakaian jadi dan produk tekstil sudah jadi lainnya, serta alas kaki (Kemenperin RI, 2019). Lonjakan nilai impor ini diduga terjadi karena para importir barang lartas yang di-post borderkan memanfaatkan kelemahan pengawasan di luar kawasan pabean tersebut. Kondisi ini bila berlangsung terus dapat menimbulkan ketidakpastian berupa gangguan atas rencana pengembangan produk industri domestik.

Kebijakan post border yang bertujuan meningkatkan efisiensi perekonomian ternyata disertai oleh indikasi inefisiensi akibat timbulnya sejumlah ketidakpastian. Dengan demikian diperlukan studi untuk menganalisis kemungkinan terjadinya ironi dalam kebijakan post border ini. Penelitian ini memiliki rumusan masalah: bagaimana dampak yang ditimbulkan oleh kebijakan post border dalam aspek kepastian regulasi pemeriksaan impor? Tujuan penelitian adalah mengungkapkan fakta tentang dugaan adanya ketidakpastian yang ditimbulkan oleh kebijakan ini beserta solusi-solusi yang dapat diambil. Mengingat kebijakan post border adalah suatu pilihan kebijakan baru dalam regulasi kepabeanan, khususnya untuk barang impor lartas, para akademisi perlu mencermati temuan penelitian ini tentang bagaimana pembentukan argumentasi-argumentasi di balik kebijakan baru tersebut. Pembahasan hasil penelitian ini diharapkan dapat berkontribusi bagi khazanah analisis kebijakan publik di Indonesia, khususnya di bidang perdagangan. Studi ini adalah suatu contoh kasus bahwa kebijakan publik Indonesia hingga kini masih menghadapi tantangan penyelesaian suatu masalah secara efektif tanpa menimbulkan masalah-masalah baru. Para pelaku usaha perlu belajar dari penelitian ini bagaimana mengantisipasi terjadinya ketidakpastian atas suatu kebijakan publik, agar tetap dapat menjaga efisiensi produksi serta kepentingan-kepentingan perusahaan lainnya.

\section{TINJAUAN PUSTAKA}

Hingga saat ini belum ada literatur ilmiah di Indonesia yang membahas kebijakan post border karena relatif masih barunya penerapan kebijakan ini. Juga belum ada laporan Kementerian/Lembaga ataupun penelitian tentang dampak kebijakan post border ini. Perlu dicatat bahwa istilah "post border" sendiri praktis tidak dikenal dalam forum-forum ilmiah bidang perdagangan internasional, khususnya yang berhubungan dengan kepabeanan. Studi-studi yang telah banyak dilakukan umumnya tentang efektivitas kegiatan kepabeanan di Indonesia. Misalnya sebuah studi tentang pemeriksaan fisik barang pada Ditjen Bea dan Cukai menemukan adanya tingkat kesalahan sebesar 5.9\% dalam pengisian dokumen Pemberitahuan Impor Barang (PIB) (Firdiansyah \& Nugroho, 2017).

Ada pula temuan terkini yang menunjukkan kelemahan sumber daya manusia dalam pengawasan atas kegiatan impor barang di lingkungan kementerian. Kebijakan post border dimaksudkan untuk mempermudah prosedur kepabeanan dengan mengandalkan pengawasan oleh kementerian/lembaga daripada Ditjen Bea dan Cukai Kemenkeu. Dalam suatu studi terungkap bahwa Kementerian Kelautan dan Perikanan hanya memiliki 270 pegawai untuk mengawasi kegiatan ekspor-impor komoditas perikanan di Indonesia (Arthatiani \& Deswati, 2020). Studi ini menunjukkan bahwa penerapan kebijakan post border berpotensi menghadapi kendala efektivitas pengawasan oleh kementerian/lembaga.

Sementara itu, Bank Dunia setiap tahun menyampaikan evaluasi kinerja kepabeanan negara-negara anggotanya melalui laporan Doing Business, yaitu di bagian "trading across borders". Bahkan untuk Doing Business edisi 2020, terdapat laporan khusus tentang Indonesia. Dalam laporan tersebut terdapat topik "Trading across borders" yang mencakup indikator waktu dan yang biaya yang dibutuhkan untuk memenuhi prosedur ekspor-impor dengan mengambil sampel kota Jakarta dan Surabaya. Peringkat Indonesia untuk topik ini adalah 119 dari 190 negara dengan skor 67.5, dimana skor maksimum adalah 100 (World Bank, 2019). Hal ini 
mengindikasikan kinerja kepabeanan yang belum memuaskan. Namun dalam laporan ini tidak ada pembahasan tentang regulasi yang berhubungan dengan kepabeanan.

\section{METODE PENELITIAN}

Metodologi yang digunakan untuk menjawab permasalahan dalam studi ini adalah Regulatory Impact Analysis (RIA). Pendekatan RIA secara sistematis menilai secara kritis dampak positif maupun negatif dari kebijakan yang sudah ada maupun yang sedang direncanakan, serta dampak yang dapat ditimbulkan dari alternatif non-kebijakan lainnya (OECD, 2015). Sebagai alat evaluasi kebijakan, keunggulan RIA terletak pada penempatan konsultasi pemangku kepentingan sebagai penentu utama dalam tahap-tahap yang terdapat dalam metode ini. Metode-metode evaluasi kebijakan lainnya tidak ada yang menempatkan konsultasi publik sebagai fokus analisis mereka. Tahap-tahap dalam RIA secara rinci mengamati suatu regulasi sejak kemunculan masalah hingga penyusunan strategi pelaksanaan regulasi tersebut. Hal ini memperkecil risiko adanya hal penting yang terlewati seperti yang mungkin dialami pendekatan-pendekatan evaluasi kebijakan lainnya. TABEL-1 berikut ini menyajikan langkahlangkah RIA:

TABEL-1: Tahapan dalam Regulatory Impact Assessment (RIA)

\begin{tabular}{|c|c|}
\hline \multirow{5}{*}{$\begin{array}{l}\text { Konsultasi pemangku } \\
\text { kepentingan: } \\
\sim \text { Konsultasi antar lembaga } \\
\quad \text { pemerintahan } \\
\sim \text { Konsultasi publik }\end{array}$} & $\begin{array}{ll}\text { 1. } & \text { Perumusan masalah: menganalisis masalah yang } \\
\text { mendasar, pelaku dan dampaknya. }\end{array}$ \\
\hline & $\begin{array}{l}\text { 2. Perumusan tujuan: menganalisis ketepatan tujuan } \\
\text { sebuah kebijakan atau tindakan. }\end{array}$ \\
\hline & $\begin{array}{l}\text { 3. Perumusan alternatif: mempertimbangkan alternatif } \\
\text { regulasi dan non regulasi. }\end{array}$ \\
\hline & $\begin{array}{l}\text { 4. Analisis manfaat dan biaya: menganalisis manfaat dan } \\
\text { biaya untuk seluruh alternatif sehingga terpilih suatu } \\
\text { alternative. }\end{array}$ \\
\hline & $\begin{array}{l}\text { 5. Strategi implementasi: mencari strategi implementasi } \\
\text { untuk melaksanakan alternatif tindakan yang dipilih }\end{array}$ \\
\hline
\end{tabular}

Sumber: Pedoman Penerapan RIA (Bappenas, 2009)

Idealnya, setiap tahapan RIA harus terlebih dahulu dikonfirmasi melalui konsultasi pemangku kepentingan, untuk memastikan bahwa apa yang dirumuskan oleh tim pelaksana RIA adalah benar-benar mencerminkan kondisi masyarakat.

Data yang digunakan dalam studi ini meliputi data primer maupun data sekunder. Data primer pada studi ini diperoleh dari wawancara serta rangkuman diskusi dengan pemangku kepentingan utama dari pengimplementasian regulasi post border, yaitu pihak pemerintah dan pihak pelaku usaha. Pihak pemerintah antara lain terdiri dari pejabat-pejabat serta perwakilan dari Kementerian Perindustrian, Kementerian Perdagangan, Ditjen Bea dan Cukai Kementerian Keuangan serta Dinas Perindustrian dan Perdagangan Provinsi Jawa Barat. Sedangkan pelaku usaha diwakili oleh pimpinan sejumlah asosiasi pelaku usaha, Kadin Provinsi Jawa Barat serta Pusat Logistik Berikat di Kawasan Berikat Nusantara (KBN) di Marunda, Jakarta Utara. Data sekunder pada studi ini meliputi data resmi pemerintah, yaitu sejumlah Undang-undang, Peraturan Menteri serta regulasi-regulasi lainnya. Sementara itu, data perdagangan mengacu ke publikasi Badan Pusat Statistik (BPS).

\section{HASIL ANALISIS DAN PEMBAHASAN}


Pembahasan yang dilakukan terhadap kebijakan post border ini disesuaikan dengan tahaptahap yang ada dalam metode RIA yaitu dimulai dengan tahap perumusan masalah dan tujuan dan diakhiri dengan tahap strategi implementasi.

\subsection{Tahap Perumusan Masalah dan Tujuan}

Tahapan pertama metode RIA adalah menganalisis perumusan masalah yang timbul serta tujuan dibuatnya suatu regulasi. Paket Kebijakan Ekonomi Tahap XV tentang Pengembangan Usaha dan Daya Saing Penyedia Jasa Logistik Nasional diumumkan oleh Kemenko Perekonomian pada pertengahan 2017. Tujuan keempat (IV) dari Paket ini adalah mempermudah dan mempercepat arus barang di pelabuhan melalui kebijakan (butir 18) penyederhanaan peraturan tata niaga ekspor-impor. Penyederhanaan tata niaga impor dilakukan dengan cara, antara lain, mengurangi jumlah barang yang terkena lartas impor di border, dengan melakukan pergeseran pemeriksaan barang impor lartas ke post border. Kebijakan post border mulai berlaku sejak 1 Februari 2018.

Pemeriksaan pemenuhan persyaratan atas barang impor lartas (yaitu sebanyak 5.229 HS atau $48,3 \%$ dari total 10.826 HS) akan dibagi sebagai berikut: di border sebanyak 2.256 (20,8\% dari total HS) dan post border sebanyak 3.466 (32,02\% dari total HS) (Kemenko Perekonomian RI, 2018). Penyederhanaan tata niaga tersebut bertujuan mendorong daya saing industri yang membutuhkan bahan baku impor, daya saing ekspor, dan efisiensi kebutuhan konsumsi serta memenuhi komitmen kerjasama perdagangan internasional dimana persentase komoditas yang terkena Non-Tariff Barrier (Hambatan Non Tarif) ASEAN sudah rata-rata 17\% dan komitmen World Trade Organization (WTO) Schedule XXI (Kemenko Perekonomian RI, 2018).

Secara ringkas, pemerintah beranggapan bahwa ada masalah berupa persentase barang impor yang terkena lartas lebih besar dibanding rata-rata persentase pengenaan hambatan non tarif oleh negara-negara ASEAN. Padahal Indonesia sudah memiliki komitmen untuk menurunkan persentase hambatan non tarif tersebut sesuai perjanjian perdagangan internasional di tingkat ASEAN dan juga WTO Schedule XXI. Namun, tidak ada penjelasan rinci tentang komitmen tersebut. Seperti apa persisnya komitmen tersebut? Apakah ada jadwal tertentu yang harus diikuti oleh seluruh anggota ASEAN/WTO? Apa sanksinya bila jadwal tersebut tidak bisa diikuti? Apakah jadwal ini berhubungan dengan angka 32,02\% yang merupakan persentase barang impor terkena lartas yang akan di-post border-kan? Bagaimana kriteria pemilihan komoditas yang akan di-post border-kan? Penelusuran penulis terhadap dokumen WTO Schedule XXI (situs resmi WTO: https://ocs.wto.org) tidak memberikan petunjuk tentang adanya permasalahan yang dapat ditimbulkan akibat tidak diikutinya jadwal tersebut.

Kebijakan post border mengharuskan dilakukannya perubahan regulasi di sejumlah kementerian/lembaga, terutama ketentuan impor berbagai jenis barang yang diatur oleh Kementerian Perdagangan dalam sejumlah Peraturan Menteri Perdagangan atau Permendag. TABEL-2 merupakan contoh sejumlah Permendag tersebut beserta revisi-revisinya.

TABEL-2: Beberapa Peraturan Menteri Perdagangan tentang Kebijakan Post Border

\begin{tabular}{|c|ll|}
\hline No. & Peraturan Menteri Perdagangan beserta tanggal penetapannya \\
\hline 1 & Permendag 3/2018 & ketentuan impor mutiara (10 Januari 2018) \\
\hline 2 & Permendag 6/2018 & ketentuan impor ban (10 Januari 2018) \\
\cline { 2 - 3 } & Permendag 117/2018 & ketentuan impor ban (19 Desember 2018) \\
\cline { 2 - 3 } & Permendag 5/2019 & ketentuan impor ban (30 Januari 2019) \\
\hline 3 & Permendag 12/2018 & ketentuan impor produk tertentu (10 Januari 2018) \\
\hline
\end{tabular}




\begin{tabular}{|c|ll|}
\hline No. & Peraturan Menteri Perdagangan beserta tanggal penetapannya \\
\hline \multirow{4}{*}{4} & Permendag 42/2018 & ketentuan impor produk tertentu (22 Maret 2018) \\
\cline { 2 - 3 } & Permendag 121/2018 & ketentuan impor produk tertentu (21 Desember 2018) \\
\cline { 2 - 3 } & Permendag 24/2019 & ketentuan impor produk tertentu (15 Maret 2019) \\
\cline { 2 - 3 } & Permendag 17/2018 & $\begin{array}{l}\text { ketentuan impor barang modal dalam keadaan tidak baru (10 } \\
\text { Januari 2018) }\end{array}$ \\
\cline { 2 - 3 } & Permendag 118/2018 & $\begin{array}{l}\text { ketentuan impor barang modal dalam keadaan tidak baru (19 } \\
\text { Desember 2018) }\end{array}$ \\
\hline 5 & Permendag 76/2019 & $\begin{array}{l}\text { ketentuan impor barang modal dalam keadaan tidak baru (14 } \\
\text { Oktober 2019) }\end{array}$ \\
\cline { 2 - 3 } & Permendag 110/2018 & $\begin{array}{l}\text { ketentuan impor besi atau baja, baja paduan dan turunannya } \\
\text { (5 Desember 2018) }\end{array}$ \\
\hline 6 & Permendag 28/2018 & $\begin{array}{l}\text { pelaksanaan pemeriksaan tata niaga impor di luar kawasan } \\
\text { pabean (post border) (29 Januari 2018) }\end{array}$ \\
\cline { 2 - 3 } & Permendag 74/2018 & $\begin{array}{l}\text { pelaksanaan pemeriksaan tata niaga impor di luar kawasan } \\
\text { pabean (post border) (5 Juli 2018) }\end{array}$ \\
\hline
\end{tabular}

Sumber: dihimpun oleh penulis dari berbagai sumber

Peraturan Menteri Perdagangan (Permendag) No.28 Tahun 2018 tentang Pelaksanaan Pemeriksaan Tata Niaga Impor di Luar Kawasan Pabean (Post Border) yang ditetapkan pada 29 Januari 2018 di bagian "Menimbang" menyebutkan:

a) bahwa untuk melaksanakan pemeriksaan tata niaga impor dalam rangka post border, perlu melakukan pengaturan pelaksanaan pemeriksaan tata niaga impor di luar kawasan pabean (post border);

b) bahwa berdasarkan pertimbangan sebagaimana dimaksud dalam huruf a, perlu menetapkan Peraturan Menteri Perdagangan tentang Pelaksanaan Pemeriksaan Tata Niaga Impor di Luar Kawasan Pabean (Post Border).

Bagian "Menimbang" ini tidak menyebutkan tujuan kebijakan post border itu sendiri dan tujuan ini pun tidak ditemukan dalam naskah Permendag ini. Di dalam Permendag ini juga tidak ditemukan definisi khusus tentang "post border". Sementara itu bagian "Mengingat" 2018 tidak menyebutkan suatu peraturan perundang-undangan yang secara khusus menyebutkan tentang kata "post border" ataupun "Paket Kebijakan Ekonomi Tahap XV" yang pertama kali mencantumkan istilah "post border" ini. Mengacu ke Permendag ini, tidak ditemukan penjelasan tentang adanya permasalahan yang menyebabkan perlunya dilakukan kebijakan post border. Dengan demikian, serangkaian Peraturan Menteri Perdagangan yang dibuat dalam rangka kebijakan post-border, sebagaimana Paket Kebijakan Ekonomi Tahap XV juga tidak merumuskan dengan jelas permasalahan yang ingin diatasi.

Pengumuman Paket Kebijakan Ekonomi Tahap XV pada 15 Juni 2017 berjarak relatif dekat dengan Peraturan Menteri Perdagangan RI yang paling awal mengatur kebijakan post border, yaitu Permendag No.3 Tahun 2018 (ditetapkan pada 10 Januari 2018) tentang Ketentuan Impor Mutiara. Pasal 14 Permendag ini menyebutkan ketentuan utama tentang kebijakan post border yaitu:

(1) Pemeriksaan atas pemenuhan persyaratan impor Mutiara dilakukan setelah melalui Kawasan Pabean.

(2) Persyaratan impor sebagaimana dimaksud pada ayat (1) berupa:

a. Persetujuan Impor; dan

b. Laporan Surveyor. 
(3) Importir harus membuat pernyataan secara mandiri (self declaration) yang menyatakan telah memenuhi persyaratan impor Mutiara sebelum barang impor tersebut digunakan, diperdagangkan, dan/atau dipindahtangankan.

(4) Importir harus menyampaikan pernyataan sebagaimana dimaksud pada ayat (3) secara elektronik melalui http://inatrade.kemendag.go.id dengan mencantumkan nomor Pemberitahuan Impor Barang (PIB).

(5) Importir wajib menyimpan dokumen persyaratan impor sebagaimana dimaksud pada ayat (2) dan Pemberitahuan Impor Barang (PIB) paling sedikit 5 (lima) tahun untuk keperluan pemeriksaan sebagaimana dimaksud pada ayat (1).

Pada tanggal 10 Januari 2018 tersebut juga ditetapkan belasan Permendag lainnya tentang kebijakan post border, yang contohnya dapat dilihat di TABEL-2. Dalam waktu sekitar 6 bulan sangat sulit dibayangkan ada konsultasi publik yang memadai untuk bisa menentukan permasalahan secara tepat terhadap barang-barang impor yang terkena lartas. Idealnya ada belasan hingga puluhan konsultasi publik yang melibatkan para pemangku kepentingan (kementerian/lembaga terkait, para pelaku usaha beserta asosiasi-asosiasi mereka, pemerintah daerah, dan lain-lain) sebelum Permendag-permendag tersebut ditetapkan. Namun penulis hanya menemukan satu laporan resmi tentang "Sosialisasi Penyederhanaan Regulasi dan Pengawasan Tata Niaga Impor di Post Border" yang dilaksanakan oleh Direktorat Jenderal Perdagangan Luar Negeri Kementerian Perdagangan RI pada Kamis 25 Januari 2018 di Jakarta, dengan melibatkan sekitar 200 peserta (Kemendag RI, 2018). Terdapat indikasi ketergesagesaan dalam penyusunan Permendag-permendag tersebut ketika dilakukan sejumlah revisi yang relatif cepat (dalam hitungan bulan saja) terhadap ketentuan impor sejumlah komoditas. Bahkan regulasi yang secara khusus mengatur tentang pelaksanaan kebijakan post border yaitu Permendag No.28 Tahun 2018 (ditetapkan pada 29 Januari 2018) beberapa bulan kemudian direvisi dengan Permendag No.74 (ditetapkan pada 5 Juli 2018) berupa perkuatan sistem teknologi informasi dengan melibatkan pihak swasta.

Adanya faktor ketergesa-gesaan dalam penentuan masalah dalam kebijakan post border ini mencapai puncaknya ketika terjadi pembatalan regulasi ini untuk kelompok komoditas ban serta kelompok komoditas besi atau baja dan produk turunannya. Komoditas besi dan baja terkena kebijakan post-border melalui Peraturan Menteri Perdagangan No.22 Tahun 2018 yang merevisi Permendag No.82/M-DAG/PER/12/2016 tentang Impor Besi atau Baja, Baja Paduan, dan Produk Turunannya. Permendag No.110 Tahun 2018 (diundangkan pada 20 Desember 2018) telah mengembalikan kebijakan impor besi dan baja ke kawasan pabean seperti sebelumnya.

Pasal 35 Permendag No.110 Tahun 2018 menyatakan pencabutan Permendag No.22 Tahun 2018 (ditetapkan pada 10 Januari 2018) yang sebelumnya mengatur tentang kebijakan post border. Bagian "Menimbang" Permendag No.110 Tahun 2018 menyebutkan bahwa kebijakan sebelumnya tentang impor besi atau baja, baja paduan, dan produk turunannya sudah tidak sesuai lagi dengan perkembangan dan kebutuhan hukum masyarakat sehingga perlu diganti. Selain itu revisi dilakukan untuk mendorong peningkatan daya saing nasional serta meningkatkan efektivitas impor besi atau baja, baja paduan, dan produk turunannya. 
TABEL-4 : Impor Sejumlah Produk Besi dan Baja oleh Indonesia dari Dunia dan RRT Tahun 2017-2018

\begin{tabular}{|c|c|c|c|c|c|c|c|c|}
\hline \multirow{2}{*}{$\begin{array}{l}\text { Kode } \\
\text { HS }\end{array}$} & \multicolumn{3}{|c|}{2017} & \multicolumn{3}{|c|}{2018} & \multirow{2}{*}{$\begin{array}{l}\text { Ptbhan } \\
\text { Impor } \\
\text { Total } \\
17-18\end{array}$} & \multirow{2}{*}{$\begin{array}{l}\text { Ptbhan } \\
\text { Impor } \\
\text { dari RRT } \\
17-18\end{array}$} \\
\hline & $\begin{array}{l}\text { Nilai } \\
\text { Impor } \\
\text { Total } \\
\text { (juta } \\
\text { USD) }\end{array}$ & $\begin{array}{l}\text { Nilai } \\
\text { Impor } \\
\text { dari } \\
\text { RRT } \\
\text { (juta } \\
\text { USD) }\end{array}$ & $\begin{array}{l}\% \\
\text { RRT } \\
\text { thd } \\
\text { Total } \\
\text { Impor }\end{array}$ & $\begin{array}{l}\text { Nilai } \\
\text { Impor } \\
\text { Total } \\
\text { (juta } \\
\text { USD) }\end{array}$ & $\begin{array}{l}\text { Nilai } \\
\text { Impor } \\
\text { dari } \\
\text { RRT } \\
\text { (juta } \\
\text { USD) }\end{array}$ & $\begin{array}{l}\text { \% RRT } \\
\text { thd } \\
\text { Total } \\
\text { Impor }\end{array}$ & & \\
\hline 7208 & 806 & 60 & 7.42 & 860 & 29 & 3.38 & 6.67 & -51.43 \\
\hline 7209 & 547 & 25 & 4.50 & 575 & 37 & 6.39 & 5.24 & 49.53 \\
\hline 7210 & 68 & 129 & $\begin{array}{ll}18.98 \\
\end{array}$ & 653 & 143 & 21.93 & -4.06 & 10.83 \\
\hline 7212 & 271 & 18 & 6.45 & 306 & 19 & 6.24 & 12.87 & 9.13 \\
\hline 7214 & 111 & 7 & 6.41 & 129 & 8 & 6.44 & 16.17 & 16.74 \\
\hline 7304 & 461 & 130 & 28.12 & 876 & 296 & 33.75 & 89.94 & 127.92 \\
\hline 7306 & 177 & 20 & 11.30 & 175 & 39 & 22.48 & -1.06 & 96.86 \\
\hline 7307 & 142 & 29 & 20.76 & 251 & 84 & 33.35 & 76.76 & 183.93 \\
\hline 7308 & 215 & 135 & 62.77 & 496 & 366 & 73.86 & 130.34 & 171.02 \\
\hline 7318 & 558 & 57 & 10.14 & 674 & 113 & 16.75 & 20.75 & 99.57 \\
\hline 7219 & 397 & 92 & 23.08 & 493 & 140 & 28.33 & 24.17 & 52.41 \\
\hline 7225 & 1,014 & 438 & 43.14 & 1,492 & 836 & 56.05 & 47.04 & 91.04 \\
\hline 7227 & 348 & 308 & 88.45 & 380 & 310 & 81.65 & 9.24 & 0.84 \\
\hline 7228 & 322 & 122 & 37.98 & 434 & 193 & 44.35 & 34.87 & 57.52 \\
\hline 7326 & 254 & 48 & 18.96 & 299 & 89 & 29.68 & 17.60 & 84.07 \\
\hline Total & 7,336 & 1,886 & 25.71 & 9,344 & 3,083 & 33.00 & 27.38 & 63.50 \\
\hline
\end{tabular}

Sumber: diolah dari data BPS

Media massa (Sugianto, 2019) dan (Kumparan.com, 2019) melaporkan bahwa alasan utama pengembalian pengawasan impor produk-produk besi dan baja ke border adalah karena membanjirnya produk besi dan baja impor dari Republik Rakyat Tiongkok (RRT). TABEL-4 merupakan contoh beberapa komoditas utama kelompok produk besi dan baja (kode HS 4 digit), dengan nilai total impor merupakan jumlah seluruhan impor besi dan baja yang diatur dengan Permendag No.110 Tahun 2018. Kalaupun secara total terlihat ada peningkatan impor besi dan baja yang tajam dari RRT yaitu sekitar 63\%, tidak lantas bisa kita simpulkan adanya masalah yang harus segera diatasi dengan mengembalikan impor ke border. Apalagi peran RRT dalam keseluruhan impor besi dan baja Indonesia pada 2018 hanya sekitar sepertiga.

Perlu diamati pula sejauh mana industri besi dan baja domestik telah mampu memenuhi permintaan yang ada untuk komoditas-komoditas yang strategis, sesuai kode HS 8 digit. Dengan demikian dapat diperoleh gambaran tentang kebutuhan impor yang sesungguhnya dan seberapa perlukah kita menerapkan kebijakan post border ataupun kembali ke border. Berdasarkan pengamatan atas data impor produk ban ataupun produk besi dan baja yang berhasil dihimpun oleh penulis, ternyata tidak ditemukan adanya lonjakan impor. Dengan demikian alasan pengembalian pemeriksaan impor kedua kelompok komoditas tersebut ke border, menjadi tidak jelas.

\subsection{Tahap Perumusan Alternatif}

Ketika masalah yang menyebabkan dibuatnya kebijakan post border tidak dirumuskan dengan jelas sehingga menimbulkan ketidakjelasan tujuan regulasi tersebut, maka harus 
dipertimbangan alternatif kebijakan yang perlu diambil. Hal ini merupakan tahapan berikutnya dalam RIA yaitu tahap perumusan alternatif. Berdasarkan data dan informasi yang berhasil dihimpun, penulis berpendapat bahwa kebijakan post-border berupa serangkaian Peraturan Menteri Perdagangan tentang ketentuan impor untuk ribuan produk ini memiliki isu krusial ketiadaan kriteria pemilihan produk-produk yang di-post border-kan. Kondisi ini menyebabkan kebijakan post border bersifat tidak efektif dalam mencapai tujuannya dan menimbulkan dampak negatif bagi sektor industri yaitu berupa ketidakpastian yaitu:

\section{Bagi para pelaku usaha industri}

Tiap Permendag tentang ketentuan impor tersebut mengacu kepada sekelompok produk (misalnya: "produk tertentu", "barang berbasis sistem pendingin", "besi atau baja, baja paduan dan turunannya") yang secara sekaligus di-post border-kan, tanpa membedakan apakah produk tersebut adalah bahan baku (yang diperlukan oleh industri dalam negeri) ataupun barang konsumsi. Padahal para pelaku usaha industri membutuhkan produk-produk impor tertentu untuk di-post border-kan sedangkan produk-produk impor lainnya dianggap lebih tepat untuk diawasi di kawasan pabean (border). Sebagaimana yang terjadi untuk produk ban serta besi dan baja, Pemerintah dapat menghentikan kebijakan post border tanpa disertai penjelasan yang didukung oleh data akurat. Bila penghentian ini dapat dilakukan kapan saja untuk produkproduk manapun tanpa dipandu oleh suatu kriteria, maka akan timbul ketidakpastian yang berdampak negatif bagi para pelaku usaha industri. Mereka akan kesulitan untuk membuat rencana bisnis (business plan) serta menghadapi risiko kerugian bisnis atau bahkan kebangkrutan usaha.

\section{Bagi Kementerian/Lembaga (khususnya aparat pengawasan pemenuhan ketentuan impor)}

Kebijakan post border yang diberlakukan pada l Februari 2018 secara mendadak mengharuskan Kementerian dan Lembaga (K/L) melakukan kegiatan pengawasan terhadap pemenuhan persyaratan impor atas ribuan jenis kode HS barang impor di luar kawasan pabean. Hal ini menimbulkan ketidakpastian mengingat kondisi aparat pengawasan di lingkungan K/L yang cenderung terbatas baik dalam kuantitas maupun kualitas. Apabila K/L ingin melibatkan aparat pengawasan di daerah-daerah untuk mengawasi barang-barang impor yang di-post borderkan, diperlukan kehati-hatian dalam mengikuti peraturan perundang-undangan yang ada, terutama dalam aspek alokasi anggarannya. Idealnya kebijakan post border memperhitungkan pula variabel kesiapan aparat pengawasan di luar kawasan pabean sehingga ada kriteria kesiapan aparat pengawasan atas barang-barang impor di-post border-kan.

Alternatif pertama di tahapan RIA ini adalah "do nothing", yaitu kebijakan post-border dibiarkan tanpa ada perubahan sama sekali. Melalui sejumlah diskusi publik yang diikuti penulis terungkap pula alternatif kedua yaitu revisi regulasi berupa penambahan kriteria barang impor lartas yang di-post border-kan. Alternatif ini membuat kebijakan post border dapat diarahkan agar lebih tepat sasaran dalam menentukan jenis-jenis barang impor lartas yang pemeriksaannya dilakukan di luar kawasan pabean.

\subsection{Tahap Analisis Manfaat dan Biaya}

Tahapan RIA selanjutnya adalah penentuan manfaat serta biaya untuk atas kedua alternatif tersebut. Penentuan jenis manfaat dan biaya ini dihimpun oleh penulis dari pendapat berbagai pemangku kepentingan, antara lain melalui Focus Group Discussion (FGD) yang diselenggarakan oleh Kemenperin pada bulan Juli 2019 serta diskusi dengan narasumber pejabat dari Ditjen Bea dan Cukai Kementerian Keuangan serta pejabat dari Ditjen Perlindungan Konsumen dan Tata Niaga Kementerian Perdagangan. Mengingat keterbatasan data serta 
sumber daya yang dihadapi, penulis melakukan analisis manfaat dan biaya yang bersifat kualitatif, sehingga tidak ada penilaian manfaat dan biaya dalam satuan Rupiah.

Pemilihan alternatif "do nothing" mengandung implikasi tidak adanya kriteria tentang barang-barang yang di-postborder-kan. Dengan demikian dalam konteks kehadiran suatu kriteria bagi produk-produk yang terkena kebijakan post border, tidak ada suatu manfaat (benefit) yang dihasilkan atau MAl (manfaat atas alternatif $\mathrm{l}$ ) = tidak ada

Sedangkan biaya (cost) yang timbul adalah yaitu berupa:

- $\quad B l A l$ (jenis biaya pertama yang ditimbulkan oleh alternatif 1 ) = adanya ketidakpastian bagi para pelaku usaha industri.

- B2Al (jenis biaya kedua yang ditimbulkan oleh alternatif $\mathrm{l}$ ) = adanya ketidakpastian bagi Kementerian/Lembaga.

Sedangkan alternatif revisi berupa penambahan kriteria barang-barang yang di-post borderkan dapat menimbulkan manfaat yang berkebalikan dengan biaya dalam alternatif "do nothing" yaitu:

- $\quad$ MlA2 (manfaat pertama yang ditimbulkan oleh alternatif 2$)=$ adanya kepastian bagi para pelaku usaha industri.

- $\quad$ M2A2 (manfaat kedua yang ditimbulkan oleh alternatif 2) = adanya kepastian bagi Kementerian/Lembaga.

Adapun biaya yang ditimbulkan adalah:

BA2 (biaya yang ditimbulkan oleh alternatif 2) = alokasi sumber daya oleh pemerintah (sumber daya manusia, uang, waktu, dan lain-lain) untuk menentukan kriteria bagi produk-produk yang di-post border-kan.

Selama ini penentuan komoditas yang di-post border-kan cenderung dilakukan secara keseluruhan atas kelompok-kelompok komoditas seperti keramik, produk tertentu, produk hortikultura, dan lain-lain. Padahal bagi sektor industri Indonesia, posisi tiap-tiap komoditas di dalam kelompoknya adalah berbeda-beda, antara lain sebagai berikut:

1. Bahan baku yang dibutuhkan untuk keperluan produksi komoditas ekspor dan pasokannya di dalam negeri tidak mencukupi;

2. Bahan baku yang dibutuhkan untuk keperluan produksi komoditas ekspor namun pasokannya di dalam negeri sudah mencukupi;

3. Barang konsumsi yang pasokannya di dalam negeri tidak mencukupi;

4. Barang konsumsi yang pasokannya di dalam negeri sudah mencukupi.

Dengan adanya kriteria komoditas yang di-post border-kan, maka akan mendorong proses identifikasi posisi tiap-tiap komoditas impor dalam perekonomian Indonesia secara lebih spesifik.

Kondisi sumber daya pengawasan di Kementerian/Lembaga juga harus menjadi kriteria yang dipertimbangkan dalam pembuatan kriteria produk-produk yang di-post border-kan. Sebagai ilustrasi, mengacu ke Laporan Kinerja Pusat Standardisasi Indusri (Pustan) Kemenperin RI Tahun 2018, Penyidik Pegawai Negeri Sipil (PPNS) baru yang dapat dihasilkan oleh Pustan pada tahun 2017 dan 2018 masing-masing hanya 30 dan 40 orang. Jumlah ini tentu tidak memadai dibandingkan dengan meningkatnya tugas pengawasan terhadap produk-produk impor yang di-post border-kan. Pengawasan yang harus dilakukan oleh $\mathrm{K} / \mathrm{L}$ adalah berupa post audit yaitu apakah importir produsen yang melakukan impor bahan baku telah menggunakan barang impor tersebut benar-benar untuk keperluan produksi di dalam negeri.

Mengingat begitu banyaknya produk impor serta importir yang harus diawasi, diperlukan suatu risk management yaitu tata kelola untuk melakukan pemeriksaan kepada importir bukan 
secara keseluruhan, melainkan berdasarkan profilling (proses identifikasi secara sistematis terhadap karakteristik para importir beserta kegiatan impornya untuk mendeteksi adanya kemungkinan pelanggaran hukum) yang dijalankan secara sistematis. Namun proses profilling ini tidak berjalan lancar. Sebagai ilustrasi, kebijakan post border telah mencabut sejumlah kewajiban bagi importir untuk memperoleh pertimbangan teknis atau rekomendasi dari Kemenperin RI (sebagaimana diatur dengan Permenperin No.67 Tahun 2016 tentang Pedoman Penerbitan Pertimbangan Teknis, Rekomendasi, Surat Keterangan dan Tanda Pendaftaran dengan Sistem Elektronik di Kementerian Perindustrian). Padahal proses pemberian pertimbangan teknis tersebut berperan krusial dalam mengidentifikasi kinerja para importir.

Setelah dilakukan identifikasi atas jenis-jenis manfaat dan biaya yang timbul untuk tiaptiap alternatif yang ada, selanjutnya dilakukan proses penentuan nilai atas manfaat dan biaya tersebut. Berikut ini adalah tabel-tabel ringkasan manfaat dan biaya yang ditimbulkan.

TABEL-5: Manfaat dan Biaya untuk Alternatif 1 (“do nothing”)

\begin{tabular}{|l|l|l|l|}
\hline Manfaat & \multicolumn{2}{|l|}{ Biaya } \\
\hline MAl & 0 & BlAl = ketidakpastian bagi pelaku usaha industri & $(-)$ \\
\hline & & B2Al = ketidakpastian bagi K/L & $(-)$ \\
\hline JUMLAH & 0 & JUMLAH & $2(-)$ \\
\hline
\end{tabular}

Sumber: diolah oleh penulis

Nilai BlAl dan B2Al pada TABEL-5 diwakili masing-masing oleh satu simbol negatif (-), sehingga untuk Alternatif 1 ini hanya terdapat Biaya dengan nilai 2 (-).

Sedangkan untuk Alternatif 2 (lihat TABEL 6) terdapat Manfaat yang nilainya diwakili masing-masing oleh satu simbol positif $(+)$. Total manfaat yang dapat diperoleh adalah $2(+)$. Adapun biayanya diwakili dengan satu simbol negatif (-).

TABEL-6: Manfaat dan Biaya untuk Alternatif 2 (pengaturan kriteria barang impor yang di-post border-kan)

\begin{tabular}{|l|l|l|l|}
\hline Manfaat & & Biaya \\
\hline $\begin{array}{l}\text { M1A2 = kepastian bagi pelaku } \\
\text { usaha industry }\end{array}$ & $\begin{array}{l}\text { BA2 = sumber daya untuk } \\
\text { menentukan kriteria barang impor } \\
\text { yang di-post border-kan }\end{array}$ & $(-)$ \\
\hline M2A2 = kepastian bagi K/L & $(+)$ & & $(-)$ \\
\hline JUMLAH & $2(+)$ & JUMLAH & \\
\hline
\end{tabular}

Sumber: diolah oleh penulis

Alternatif 1 hanya mengandung biaya sebesar 2(-), sehingga untuk konteks alternatif ini, penjumlahan nilai Manfaat dan Biaya akan menghasilkan 2(-). Sedangkan Alternatif 2 memiliki Manfaat dan Biaya. Jumlah nilai Manfaat pada Alternatif 2 adalah kebalikan dari nilai Biaya pada Alternatif 1 yaitu $2(+)$. Sedangkan nilai Biaya pada Alternatif 2 diasumsikan $=1(-)$ sehingga penjumlahan-penjumlahan Manfaat dan Biaya pada alternatif ini menghasilkan l(+).

Hal krusial yang perlu digarisbawahi adalah bahwa Alternatif 2 dapat menjadi pilihan yang lebih baik dari Alternatif 1 jika asumsi nilai BA2 (biaya yang ditimbulkan oleh alternatif 2) sebesar 1 (-) dapat dipenuhi.

Penulis berpendapat, asumsi nilai BA2 sebesar $1(-)$ berhubungan dengan sejumlah hal yang dianggap masih berada dalam kendali pemerintah, seperti yang terdapat dalam TABEL-7 berikut ini: 
TABEL-7 : Kondisi-kondisi yang Harus Dipenuhi agar Asumsi Nilai Biaya untuk Alternatif 2 dapat Dicapai

\begin{tabular}{|c|l|l|}
\hline No. & \multicolumn{1}{|c|}{ Variabel } & \multicolumn{1}{c|}{ Kondisi ideal } \\
\hline 1 & $\begin{array}{l}\text { Sumber daya manusia } \\
\text { (SDM) penyusun kriteria }\end{array}$ & $\begin{array}{l}\text { Dapat melibatkan SDM dari seluruh K/L terkait } \\
\text { dengan produk-produk yang di-post border-kan, } \\
\text { sehingga dapat secara optimal mensinergikan } \\
\text { kepentingan-kepentingan yang ada. }\end{array}$ \\
\hline 2 & Waktu yang diperlukan & $\begin{array}{l}\text { Dapat berlangsung dalam waktu yang tidak lebih dari l } \\
\text { tahun. }\end{array}$ \\
\hline 3 & $\begin{array}{l}\text { Anggaran yang } \\
\text { dialokasikan }\end{array}$ & $\begin{array}{l}\text { Tersedia sesuai dengan kebutuhan penyusunan } \\
\text { kriteria dalam waktu maksimum l tahun. }\end{array}$ \\
\hline
\end{tabular}

Sumber: diolah oleh penulis

Catatan penting lainnya agar asumsi nilai BA2 sebesar 1(-) terpenuhi adalah bahwa pembuatan kritera produk-produk apa saja yang di-post border-kan memerlukan sejumlah data sebagaimana dicontohkan dalam TABEL-8.

TABEL-8 : Ilustrasi Kebutuhan Data Penentuan Kriteria Barang-barang Impor yang Dipostborderkan

\begin{tabular}{|c|c|c|c|c|c|c|}
\hline \multirow{2}{*}{$\begin{array}{c}\text { Komoditas } \\
\text { (rinci hingga } \\
\text { kode HS nya) }\end{array}$} & \multicolumn{2}{|c|}{ Jenis bahan baku } & \multicolumn{2}{|c|}{$\begin{array}{c}\text { Jenis barang } \\
\text { konsumsi }\end{array}$} & \multicolumn{2}{|c|}{$\begin{array}{c}\text { Aspek pengawasan } \\
\text { ketentuan impor }\end{array}$} \\
\hline & $\begin{array}{c}\text { Pasokan } \\
\text { domestik } \\
\text { cukup }\end{array}$ & $\begin{array}{c}\text { Pasokan } \\
\text { domestik } \\
\text { kurang }\end{array}$ & $\begin{array}{c}\text { Pasokan } \\
\text { domestik } \\
\text { cukup }\end{array}$ & $\begin{array}{c}\text { Pasokan } \\
\text { domestik } \\
\text { kurang }\end{array}$ & Peraturan & $\begin{array}{c}\text { SDM } \\
\text { pengawasan }\end{array}$ \\
\hline $\begin{array}{l}\text { Kelompok } \\
\text { Ban: } \\
4011.1000 \text { (ban } \\
\text { bertekanan } \\
\text { baru dari } \\
\text { karet dari } \\
\text { jenis yang } \\
\text { digunakan } \\
\text {...dst) }\end{array}$ & & & & $X$ & $\begin{array}{l}\text { SNI wajib } \\
\text { Permenper } \\
\text { in } \\
\text { No.76/M- } \\
\text { IND/PER/ } \\
\text { 9/2015 }\end{array}$ & $\begin{array}{l}\text {.....orang } \\
\text { dengan } \\
\text { kualifikasi... } \\
\text {... }\end{array}$ \\
\hline $\begin{array}{l}\text { Kelompok } \\
\text { Besi dan baja: } \\
7214.2031 \\
\text { (Batang dan } \\
\text { batang kecil } \\
\text { lainnya dari } \\
\text { besi atau baja } \\
\text { bukan } \\
\text { paduan... dst) }\end{array}$ & $X$ & & & & $\begin{array}{l}\text { Permenper } \\
\text { in No.14 } \\
\text { Tahun } \\
2018\end{array}$ & $\begin{array}{l}\text {.....orang } \\
\text { dengan } \\
\text { kualifikasi... } \\
\text {... }\end{array}$ \\
\hline
\end{tabular}

Sumber: diolah oleh penulis

Pertama-tama harus diidentifikasi tiap-tiap barang dalam kelompoknya secara rinci sesuai dengan kode HS-nya. Kemudian ditentukan status barang sebagai bahan baku atau barang konsumsi atau bisa keduanya sekaligus. Kemudian dihimpun data tentang kondisi pasokan domestik untuk barang tersebut, apakah mencukupi atau tidak. Selanjutnya dilakukan identifikasi atas aspek pengawasan ketentuan impor, paling tidak dari segi peraturan dan kondisi sumber daya manusia pengawasannya. Untuk tiap-tiap aspek tersebut dapat dilakukan 
pembobotan untuk kemudian dilakukan pemberian skor. Barang impor yang di-post border-kan harus memiliki suatu skor tertentu.

Penulis berpendapat bahwa asumsi nilai BA2 bernilai $1(-)$ dapat tercapai sehingga Alternatif 2 (revisi kebijakan berupa penambahan kriteria barang impor yang di-post borderkan), jika Pemerintah dapat segera:

1. menghimpun data yang diperlukan untuk penentuan kriteria barang-barang yang dipost border-kan.

2. melakukan koordinasi antar $\mathrm{K} / \mathrm{L}$ dalam perumusan aturan main kepabeanan untuk barang-barang impor (baik yang di-post border-kan maupun yang pengawasan pemenuhan ketentuan impornya dilakukan di wilayah pabean).

\subsection{Tahap Strategi Implementasi}

Setelah Alternatif 2 terpilih maka di tahapan RIA ini perlu ditentukan strategi agar revisi kebijakan berupa penambahan kriteria barang impor yang di-post border-kan dapat berjalan secara efektif. Apabila telah dihasilkan, maka kriteria-kriteria yang dihasilkan harus segera disosialisasikan kepada publik melalui berbagai sarana komunikasi yang saat ini sudah terbuka luas, termasuk penggunaan media sosial seperti aplikasi WhatsApp, Facebook, Twitter, Instagram dan lain-lain.

Strategi berikutnya yang sangat krusial adalah bagaimana revisi tersebut dapat dimasukkan ke dalam sistem Indonesia National Single Window (INSW). Ada indikasi bahwa proses ini tidak selalu berjalan mulus. Fakta menunjukkan bahwa meskipun telah terjadi penghentian kebijakan post border untuk produk besi dan baja (berdasarkan Permendag No.l10 Tahun 2018) dan produk ban (berdasarkan Permendag No.117 Tahun 2018), dalam kenyataannya kedua Permendag tersebut belum dapat dilaksanakan. Bila kita cek ke situs INSW yaitu http://eservice.insw.go.id, untuk contoh produk ban yang di-post border-kan (yaitu kode HS 4011.1000 - ban bertekanan baru dari karet dari jenis yang digunakan untuk kendaraan bermotor, termasuk station wagon dan mobil balap), maka akan muncul keterangan bahwa Permendag No.117/2018 belum diberlakukan (lihat TABEL-9).

TABEL-9: Keterangan tentang Ketentuan Impor Produk Ban di Situs INSW

\begin{tabular}{|c|c|c|c|c|c|c|}
\hline No. & $\begin{array}{c}\text { Nama } \\
\text { Regulasi }\end{array}$ & Modul & Komoditi & Legal & Deskripsi & Regulasi \\
\hline 1 & $\begin{array}{l}\text { Pembatasan: } \\
\text { Nomor } \\
\text { pendaftaran } \\
\text { barang }\end{array}$ & 957 & $\begin{array}{l}\text { Komoditi } \\
\text { wajib } \\
\text { SNI }\end{array}$ & $\begin{array}{l}\text { Kementerian } \\
\text { Perdagangan } \\
\text { - Permendag } \\
\text { No.15/2018 }\end{array}$ & $\begin{array}{l}\text { Ban bertekanan, } \\
\text { baru, dari karet. } \\
\text { Dari jenis yang } \\
\text { digunakan untuk } \\
\text { kendaraan } \\
\text { bermotor } \\
\text { (termasuk station } \\
\text { wagon dan mobil } \\
\text { balap) }\end{array}$ & $\begin{array}{l}\text { Nomor } \\
\text { Pendaftar } \\
\text { an } \\
\text { Barang }\end{array}$ \\
\hline 2 & $\begin{array}{l}\text { Pembatasan: } \\
\text { Laporan } \\
\text { Surveyor }\end{array}$ & 958 & Ban & $\begin{array}{l}\text { Kementerian } \\
\text { Perdagangan } \\
\text { - Permendag } \\
\text { No.77/M- } \\
\text { DAG/PER/1l } \\
\text { /2016 jo } \\
\text { Permendag }\end{array}$ & $\begin{array}{l}\text { Ban bertekanan, } \\
\text { baru, dari karet. } \\
\text { Dari jenis yang } \\
\text { digunakan untuk } \\
\text { kendaraan } \\
\text { bermotor } \\
\text { (termasuk station }\end{array}$ & $\begin{array}{l}\text { Laporan } \\
\text { Surveyor }\end{array}$ \\
\hline
\end{tabular}




\begin{tabular}{|c|c|c|c|c|c|c|}
\hline & & & & $\begin{array}{l}\text { 06 Tahun } \\
2018\end{array}$ & $\begin{array}{l}\text { wagon dan mobil } \\
\text { balap) }\end{array}$ & \\
\hline 3 & $\begin{array}{l}\text { Pembatasan: } \\
\text { Persetujuan } \\
\text { Impor (PI) } \\
\text { Ban }\end{array}$ & 959 & Ban & $\begin{array}{l}\text { Kementerian } \\
\text { Perdagangan } \\
\text { - Permendag } \\
\text { No.77/M- } \\
\text { DAG/PER/11 } \\
\text { /2016 jo } \\
\text { Permendag } \\
\text { 06 Tahun } \\
\text { 2018 }\end{array}$ & $\begin{array}{l}\text { Ban bertekanan, } \\
\text { baru, dari karet. } \\
\text { Dari jenis yang } \\
\text { digunakan untuk } \\
\text { kendaraan } \\
\text { bermotor } \\
\text { (termasuk station } \\
\text { wagon dan mobil } \\
\text { balap) }\end{array}$ & PI Ban \\
\hline
\end{tabular}

Sumber: situs INSW http://eservice.insw.go.id (diakses pada 4 Desember 2019)

Di kolom "Legal” belum tercantum Permendag No.117 Tahun 2018 yang menyatakan bahwa kebijakan post border untuk impor produk ban telah dicabut, sehingga acuannya masih Permendag No.6/2018 (pemeriksaan di post border).

Berdasarkan informasi yang diperoleh dari narasumber Ditjen Bea dan Cukai, belum dapat dilaksanakannya Permendag No.117 Tahun 2018 terjadi karena belum dipenuhinya Peraturan Menteri Keuangan (PMK) No.224 Tahun 2015 tentang Pengawasan terhadap Impor atau Ekspor Barang Larangan dan/atau Pembatasan. Regulasi ini merupakan peraturan pelaksanaan untuk Ayat 1 dan 2 Pasal 53 UU No.17 Tahun 2006 tentang Perubahan atas UU No.10 Tahun 1995 tentang Kepabeanan, yaitu:

1) Untuk kepentingan pengawasan terhadap pelaksanaan ketentuan larangan dan pembatasan, instansi teknis yang menetapkan peraturan larangan dan/atau pembatasan atas impor atau ekspor wajib memberitahukan kepada Menteri.

2) Ketentuan mengenai pelaksanaan pengawasan peraturan larangan dan/atau pembatasan sebagaimana dimaksud pada ayat (1) diatur lebih lanjut dengan atau berdasarkan peraturan Menteri.

Pasal 2 ayat (1) s.d. (4), Pasal 3 dan Pasal 6 ayat (1) dan (2) PMK No.224/2015 menyatakan: Pasal 2

1) Barang Impor dan/atau barang Ekspor yang dilarang atau dibatasi merupakan jenis barang yang tercantum dalam peraturan yang mengatur mengenai larangan dan/atau pembatasan Impor dan/atau Ekspor, yang disampaikan oleh instansi teknis kepada Menteri untuk dilakukan pengawasan oleh Direktorat Jenderal Bea dan Cukai.

2) Instansi teknis yang menetapkan peraturan larangan dan/atau pembatasan atas Impor atau Ekspor wajib menyampaikan peraturan dimaksud kepada Menteri u.p. Direktur Jenderal sesuai contoh format sebagaimana tercantum dalam Lampiran I yang merupakan bagian tidak terpisahkan dari Peraturan Menteri ini.

3) Atas penyampaian peraturan sebagaimana dimaksud pada ayat (2), Direktur Jenderal melakukan penelitian mengenai:

a. kejelasan jenis barang yang dilarang atau dibatasi;

b. kejelasan jenis dan format dokumen/dokumen elektronik yang dipersyaratkan, dalam hal di persyaratkan;

c. kejelasan satuan barang yang digunakan dalam dokumen perizinan, dalam hal diatur kuotanya; dan

d. tersedianya instrumen administrasi yang dapat digunakan oleh Direktorat Jenderal Bea dan Cukai untuk melakukan pengawasan.

4) Dalam hal hasil penelitian sebagaimana dimaksud pada ayat (3) huruf a, huruf b, dan huruf $\mathrm{c}$ telah jelas dan instrumen administrasi sebagaimana dimaksud pada ayat (3) 
huruf $d$ telah tersedia, Direktur Jenderal atas nama Menteri menetapkan daftar barang yang dilarang atau dibatasi untuk diimpor atau diekspor.

Pasal 3

Dalam hal hasil penelitian sebagaimana dimaksud dalam Pasal 2 ayat (3) huruf a, huruf b, dan huruf c diperlukan penjelasan dari instansi teknis terkait dan/atau terdapat kendala dalam pelaksanaan peraturan larangan dan/atau pembatasan, Menteri menyampaikan kepada instansi teknis terkait.

Pasal 6

1) Dalam hal terdapat perubahan terhadap peraturan larangan dan/atau pembatasan, berlaku mutatis mutandis ketentuan penyampaian ketentuan larangan dan/atau pembatasan dan penetapan daftar barang impor atau ekspor yang dilarang atau dibatasi

2) Dalam hal peraturan larangan dan/atau pembatasan dicabut atau sudah tidak berlaku, daftar barang yang dilarang atau dibatasi dalam peraturan larangan dan/atau pembatasan dihapus dari Portal Indonesia National Single Window.

Menurut keterangan narasumber dari Ditjen Bea dan Cukai, berdasarkan proses penelitian yang telah dilakukan sesuai peraturan yang berlaku, Permendag No.110 Tahun 2018 dan Permendag No.117 Tahun 2018 belum memenuhi ketentuan perlu direvisi. Sejak pengundangan kedua Permendag tersebut pada bulan Desember 2018 hingga awal Januari 2020 (kurang lebih 1 tahun) revisi yang melibatkan puluhan produk impor tersebut belum selesai. Penulis menduga ada unsur ketidakcermatan dari Kementerian Perdagangan dalam menyusun kedua Permendag tersebut. Belajar dari pengalaman ini maka proses memasukkan revisi kebijakan post border ke dalam sistem INSW memerlukan koordinasi yang erat dengan Ditjen Bea dan Cukai Kementerian Keuangan RI.

\section{KESIMPULAN DAN REKOMENDASI}

Melalui penerapan metode Regulatory Impact Assessment (RIA) dapat disimpulkan bahwa kebijakan post border pada awal 2018 diambil tanpa melalui konsultasi publik serta pertimbanganpertimbangan yang memadai, sehingga menyebabkan terjadinya sejumlah ketidapastian. Penentuan barang-barang impor yang di-post border-kan dilakukan secara berkelompok dan belum membedakan karakteristik produk sebagai bahan baku atau barang konsumsi serta belum memperhitungkan kondisi pasokan di dalam negeri (apakah mencukupi atau tidak). Selain itu, kondisi kemampuan sumber daya pengawas oleh Kementerian/Lembaga juga belum diperhitungkan.

Melalui penerapan metode RIA telah dihasilkan usulan revisi atas kebiakan post border berupa penambahan kriteria atas barang impor lartas yang di-post border-kan. Alternatif ini bisa diambil jika Pemerintah dapat segera menghimpun data yang diperlukan serta melakukan koordinasi antar Kementerian/Lembaga dengan sangat baik.

Bagi para akademisi, temuan studi ini mengandung implikasi perlunya disusun pertimbanganpertimbangan ilmiah untuk menentukan kriteria yang tepat bagi barang impor lartas yang di-post border-kan. Misalnya saja analisis posisi suatu barang impor lartas dalam mata rantai pasokan suatu jenis komoditas.

Implikasi bagi pembuat kebijakan adalah pembentukan tim penyusun kriteria barang impor lartas yang di-post border-kan di bawah koordinasi Kemenko Perekonomian agar proses distribusi kewenangan dan pencapaian konsensus antar Kementerian/Lembaga dapat berjalan dengan lancar. 
Selain itu perlu dilakukan penyusunan jadwal yang jelas tentang tahap-tahap yang akan dilalui dalam proses penentuan kriteria ini sehingga waktu yang diperlukan dapat lebih terukur. Satu hal lagi adalah alokasi anggaran yang memadai yaitu sesuai dengan standar pembuatan kebijakan yang memerlukan koordinasi antar K/L di tingkat Kemenko Perekonomian.

Para pelaku usaha, khususnya para importir, perlu secara proaktif mengusulkan penentuan kriteria barang lartas yang di-post border-kan serta menjelaskan kendala-kendala teknis yang mereka hadapi dalam memenuhi ketentuan regulasi post border. Studi berikutnya yang menurut hemat penulis perlu dilakukan adalah tentang peninjauan kembali persyaratan-persyaratan yang harus dipenuhi oleh barang-barang impor lartas. Harus ada argumentasi yang jelas untuk setiap persyaratan agar tidak timbul biaya-biaya yang sebenarnya tidak diperlukan sehingga dapat meningkatkan efisiensi perekonomian, khususnya di bidang perdagangan.

\section{UCAPAN TERIMA KASIH}

Penulis mengucapkan terima kasih kepada rekan-rekan dari Lembaga Penyelidikan Ekonomi dan Masyarakat (LPEM) Fakultas Ekonomi Universitas Indonesia: Budhi Ismayadi, Devianto Suratno, M.D.Revindo dan Sean Hambali yang telah banyak membantu dalam keseluruhan proses penulisan kajian ini.

\section{DAFTAR PUSTAKA}

Arthatiani, F. Y., \& Deswati, R. H. (2020). Strategi Pengendalian Impor Mackarel Sebagai Bahan Baku Usaha Pemindangan. Jurnal Kebijakan Sosial Ekonomi Kelautan dan Perikanan, 10(1), 39-52.

Bappenas. (2009). Pedoman Penerapan Regulatory Impact Assessment (RIA). Jakarta: Bappenas. Firdiansyah, A., \& Nugroho, A. S. (2017). Evaluasi kebijakan pemeriksaan fisik barang pada Direktorat Jenderal Bea dan Cukai. Jurnal Perspektif Bea dan Cukai, 1(1), 1-9.

Kemendag RI. (2018, January 25). Sosialisasi penyederhanaan regulasi dan pengawasan tata niaga impor di post border. Retrieved from http://ditjendaglu.kemendag.go.id/index.php/home/detail_news/271

Kemenko Perekonomian RI. (2017). Siaran pers: Efisiensi logistik meningkatkan daya saing.

Kemenko Perekonomian RI. (2018). Kebijakan percepatan pelaksanaan berusaha melalui sistem OSS.

Kemenko Perekonomian RI. (2018). Penyederhanaan tata niaga impor: pengalihan pengawasan border ke post border.

Kemenperin RI. (2019). Memo Dinas: data/informasi terkait dampak kebijakan pergeseran pengawasan ketentuan lartas ke post-border bagi sektor IKTF.

Kumparan.com. (2019). Mendag salahkan China karena RI kebanjiran baja impor. Retrieved from https://kumparan.com/kumparanbisnis/mendag-salahkan-china-karena-rikebanjiran-baja-impor-1548922944737147909

OECD. (2015). Regulatory Impact Analysis. Retrieved from www.oecd.org/regreform/regulatory-policy/ria.htm

Pratomo, M. (2017). Pengawasan post border menambah biaya logistik. Retrieved from https://ekonomi.bisnis.com/read/20170922/257/692139/pengawasan-post-bordermenambah-biaya-logistik

Prima, B. (2019). Kebijakan post border berpotensi dimanfaatkan karena pengawasan lemah. Retrieved from https://nasional.kontan.co.id/news/kebijakan-post-borderberpotensi-dimanfaatkan-karena-pengawasan-lemah 
Sugianto, D. (2019). Banjir baja dari China, Mendag curiga ada penyimpangan. Retrieved from https://finance.detik.com/industri/d-4379167/banjir-baja-dari-china-mendagcuriga-ada-penyimpangan

Suwiknyo, E. (2018). Pemerintah perketat pengawasan post border. Retrieved from https:/ekonomi.bisnis.com/read/20180815/9/828318/pemerintah-perketatpengawasan-post-border

World Bank. (2019). Doing business 2020: economy profile - Indonesia. Washington D.C.: World Bank. 